\title{
並列計算機を用いた電子ホログラフィにおける負荷分散 の最適化
}

Optimization of Load Distribution in Electronic Holography with a Parallel Computer

正会員 田 中 一 行 $^{\dagger}$, 高 橋 秀 $也^{+\dagger}$, 正会員 志 水 英 二十+

Kazuyuki Tanaka ${ }^{\dagger}$, Hideya Takahashi ${ }^{\dagger \dagger}$ and Eiji Shimizu ${ }^{\dagger+}$

\begin{abstract}
Although electronic holography requires a large number of computations, we succeeded in generating holographic images, even moving images, using a parallel computer "CYBERFLOW" with 64 processors. Because of the computer's performance, however, the number of point sources in the image was limited. In this paper, we attempt to speed up the generation of images including more point sources, using a CYBERFLOW with 128 processors. Generation speed, however, does not increase in proportion to the number of processors with our conventional method of distributing the hologram among the processors, because this method results in differences between their loads. We propose an algorithm that distributes the hologram among the processors so that the difference between their loads can be reduced. Applying this algorithm to the 128 processors, we achieve a generation speed that is 2.76 times higher than that of the conventional method. We also propose a method for finding the most appropriate value of the parameter for the dynamic distribution.
\end{abstract}

キーワード：電子ホログラフィ, 計算機合成ホログラム, デー夕駆動計算機, 並列処理, 並列化, 負荷分散

\section{1. ま え がき}

立体映像に対する関心が高まる中，人間が立体を知覚す る要素をすべて備えた理想的な立体表示技術であるホログ ラフィが注目されている ${ }^{1) ~ 3)}$ また，ホログラムを電子的 に生成する電子ホログラフィ4) は理想的な立体テレビジョ ンとして期待されている。電子ホログラフィにはホログラ ムを計算機によって生成する計算機合成ホログラム (CGH) が広く用いられている。しかし, CGH の生成に は膨大な量の計算が必要であり, 従来の計算機の処理能力 ではリアルタイムに生成することが不可能であった。そこ で筆者らは，CGH に内在する高い並列性に着目し，64プ ロセッサを備えたデータ駆動型並列計算機 CYBERFLOWを用いて並列処理を行うことにより, CGHによ るリアルタイム動画生成に成功している5)6)。しかしなが ら, CGH の計算量は表示する物体の点光源数に比例する ため,これは簡単な画像に限られていた。

一方, CGH に内在する並列性は極めて高いため, 計算

1996 年 11 月 5 日, テレビジョン学会映像表現研究会で発表

1997 年 3 月 31 日受付, 1997 年 11 月 17 日最終受付, 1997 年 12 月 8 日採録

$\dagger$ 財団法人イメージ情報科学研究所

（テ 565 豊中市新千里西町 1-1-8, TEL 06-836-0256)

† 大阪市立大学 工学部 電気工学科

( 5558 大阪市住吉区杉本 3-3-138, TEL 06-605-2679)

$\dagger$ Laboratories of Image Information Science and Technology

(1-1-8, Shinsenri-Nishimachi, Toyonaka-shi, Osaka 565, Japan)

$\dagger \dagger$ Faculty of Engineering, Osaka City University

(3-3-138, Sugimoto, Sumiyoshi-ku, Osaka 558, Japan)
機の並列度を向上させることにより, 陰影処理された画像 のような更に多くの点光源を含む画像のリアルタイム生成 も可能になると考えられる. しかし, 各プロセッサの負荷 にばらつきがあると, プロセッサ数に比例した処理速度の 向上は期待できない.つまり, 並列計算機の処理能力を最 大限に引き出すためには, 各プロセッサの負荷が均等にな るような最適な並列化を行う必要がある.

そこで本論文では, このような多数の点光源を含む $\mathrm{CGH}$ の高速生成を目指し, 各プロセッサの負荷の差を縮 小することができる並列化アルゴリズムを提案する。ま た, 従来の 2 倍の 128 プロセッサを備えた並列計算機 CYBERFLOW-128 を用いて実験を行い, 本並列化アル ゴリズムの有効性を検証する.さらに, 多数の点光源を含 むリアルタイム動画ホログラムの実現を目指し, 本並列化 アルゴリズムにおける最適なパラメータを動的に決定する 方法を提案する。

\section{2. システム構成}

\section{1 電子ホログラフィシステム}

図 1 に本電子ホログラフィシステムの構成を示す．空間 光変調器には音響光学素子 $(A O D)$ を使用しており, 並列 計算機 CYBERFLOW で生成された CGH データがビデ オ信号として AOD に入力される. AODではこの入力信 号に応じた屈折率変化が生じ, 入射レーザ光が回折され る.これをガルバノミラー, ポリゴンミラーによって垂 


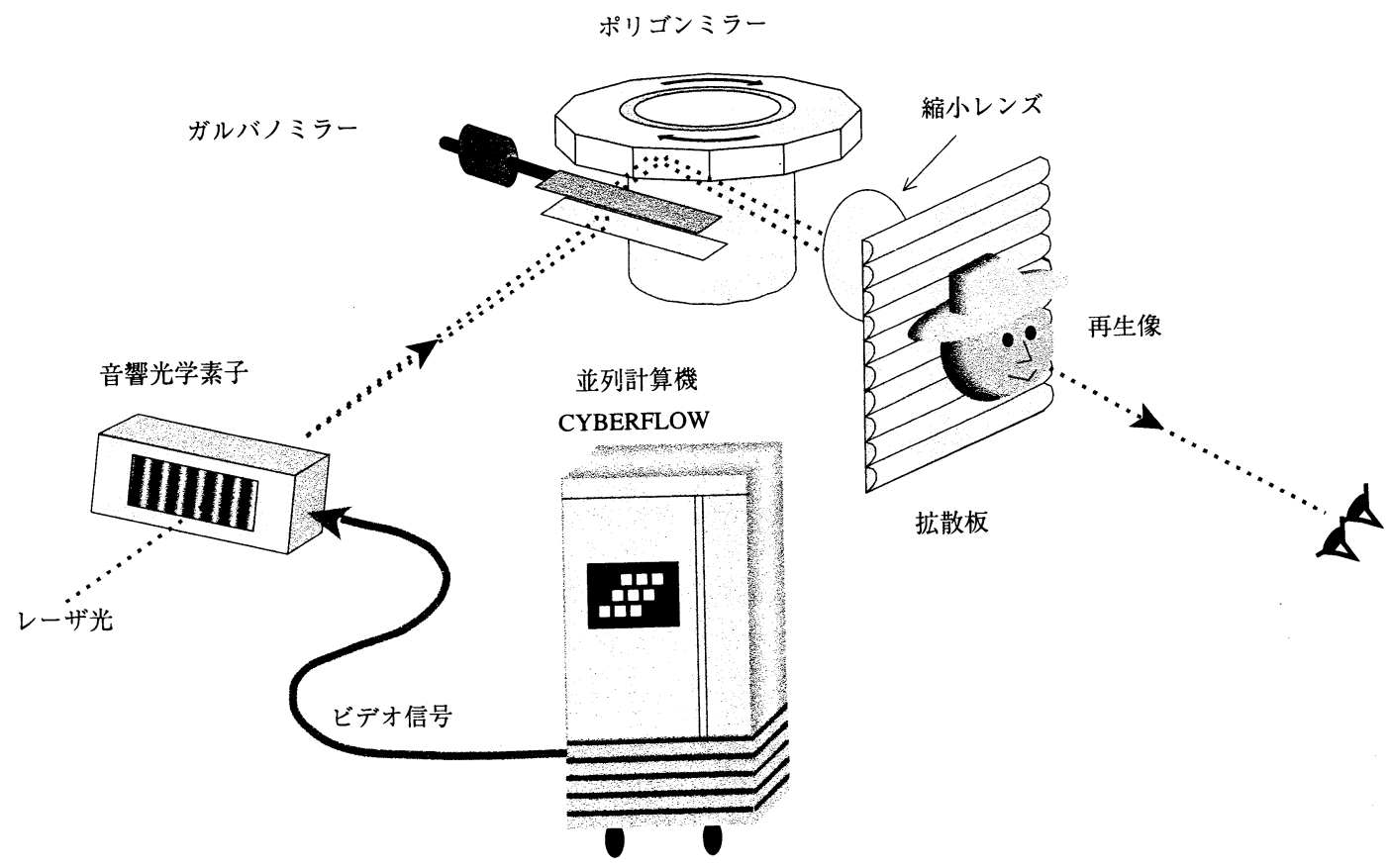

図 1 電子ホログラフィシステムの構成

Constitution of the electronic holography system.

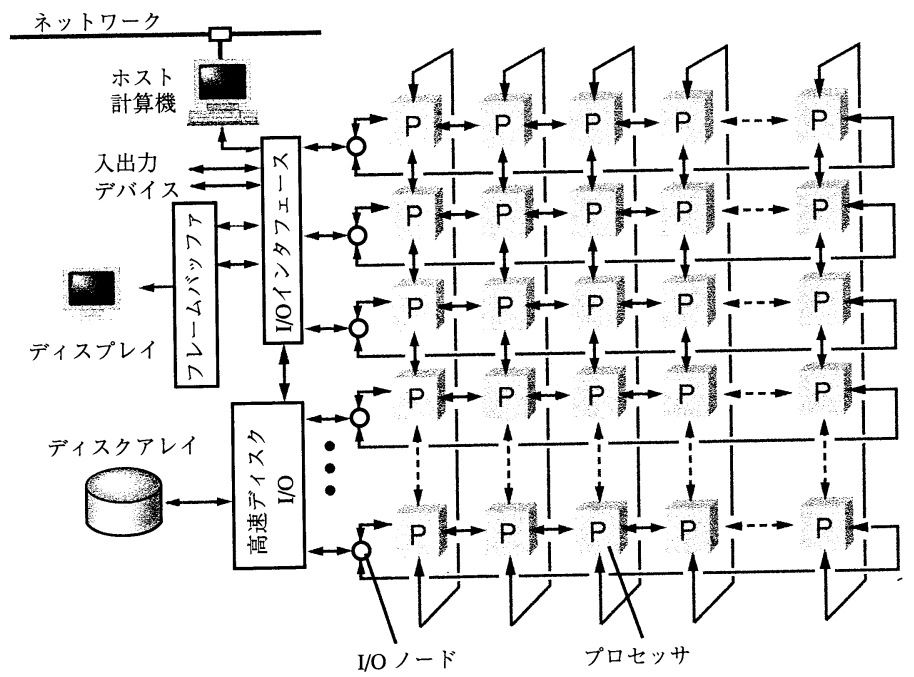

図 2 並列計算機 CYBERFLOW の構成

Architecture of the parallel computer CYBERFLOW.

直，水平にそれぞれ走査することによって再生像が得られ る. 一方, AOD の回折角は約 $3^{\circ}$ と極好さいため, 再 生像をレンズで縮小することにより, 約 $8^{\circ}$ の視域を得て いる．また，計算量を削減するために垂直方向の視差情報 を削除しているため, 縦方向のみに拡散する拡散板を通し て再生像を観察する。

\section{2 並列計算機 CYBERFLOW}

CYBERFLOW は非ノイマン型計算機の一種であり, 問題に内在する並列性を自然に引き出すことができるデー 夕駆動方式の並列計算機である7). 図 2 に示すように, 多 数のプロセッサが 2 次元トーラス状に相互接続されて構成 され，各プロセッサがローカルメモリーを備えた分散メモ

\section{リー方式を採用している。}

各プロセッサは 4 系統の通信ポートによりプロセッサ間 通信を行う通信制御部と, 演算などの命令を実行する循環 パイプライン構造の命令処理部から構成されており,これ らは並列に動作する。また，命令処理部は通常の演算と並 列実行可能なベクトル演算機構を備えており, 多数のデー 夕に対して同一の演算を行うような処理を一括して高速に 実行できる。これはCGH の計算に極めて有効であり，大 幅な高速化が図れる5).なお，一度のベクトル演算で実行 できる最大要素数は 4096 である。

一方, 多数のプロセッサが結合されて構成されているプ ロセッサ結合網には I/O インタフェースが挿入されてお 
り，これを介して各プロセッサの演算結果を $1280 \times 1024$ 画素のフレームバッファに即時描画することができる．本 電子ホログラフィシステムでは, このフレームバッファに 水平方向の要素ホログラム数 40960 , 垂直方向の解像度 32 ラインの CGH 干渉縞を書込んでいる.

CYBERFLOW はプロセッサ数が可変であり, 論理的 には最大 1024 プロセッサを接続することができる. 今回， 従来の 64 プロセッサ構成の CYBERFLOW-64に代えて 128 プロセッサ構成のCYBERFLOW-128を使用した。 その最大性能は 1.28 GFLOPS である。

\section{3. 計算機合成ホログラムの生成}

通常の光学ホログラムが光の干渉を干渉縞として記録す るのに対して,この干渉縞を計算機で生成したものが計算 機合成ホログラム $(\mathrm{CGH})$ であり, 電子ホログラフィにお いて広く用いられている8) 10). この干渉縞は物体を点光源 の集合として定義し, 次のよう各点光源に対する参照光と の干渉を計算することによって求められることが知られて 抢り, 筆者らも従来よりこの方法で CGH を生成してい $3^{5) 6)}$.

すなわち, ある点光源 $i$ からの物体光のホログラム面上 の複素振幅 $O_{i}(x, y, t)$, 参照光の複素振幅 $R(x, y, t)$ を それぞれ

$$
\begin{aligned}
& O_{i}(x, y, t)=A_{i} \exp \left\{j \phi_{i}(x, y)+j \omega t\right\} \\
& R(x, y, t)=A_{R} \exp \left\{j \phi_{R}(x, y)+j \omega t\right\}
\end{aligned}
$$

と表すと

$$
H(x, y)=\sum_{i=1}^{n} A_{i} \cos \left(\phi_{R}-\phi_{i}\right)
$$

を計算すれば点 $(x, y)$ における要素ホログラムを求めるこ とができる3).ここで, $A_{i}, A_{R}$ はそれぞれ点光源 $i$ から の物体光の複素振幅の係数, 参照光のそれであり, いずれ も定数である.また， $\phi_{i}, \phi_{R}$ は，それぞれ点光源 $i$ の位 相, 参照光のそれであり, ホログラム面上の座標の関数で ある。

しかしながら，（3 )式の計算量は膨大であるため, 筆者 らは情報量を削減するために，立体の認識にとって水平方 向の視差情報に比べて余り重要でない垂直方向の視差情報 は削除してきた。また，サンプリング定理により CGH の 空間周波数は, 音響光学素子が応答可能なホログラム信号 の最高サンプリング周波数 $f_{s}$ によって制限される.すな わち, $f_{s} / 2$ を越える空間周波数が $\mathrm{CGH}$ に含まれている と, 再生される干渉縞に歪みが発生する。これを防ぐため に， $f_{s}$ にって決まる音響光学素子の回折範囲に含まれ ない情報は削除しなければならない.すなわち, この回折 角を $\theta, \mathrm{CGH}$ の最大空間周波数を $f_{h}$, 入射光の波長を $\lambda$ とすると

$$
f_{h} \lambda=\sin \theta
$$

であるから, サンプリング定理より

$$
f_{s} \lambda / 2=\sin \theta
$$

となる ${ }^{4)} . \theta$ は極めて小さいので, 縮小レンズを考慮した 回折範囲 $\alpha$ は

$$
\alpha=2 \theta / m \fallingdotseq f_{s} \lambda / m
$$

で求められる。ここで, $m$ はレンズの倍率である.つま り，(3)式のうち水平方向の各 1 次元ホログラムと同一 $x-z$ 平面上に存在する点光源のみを計算の対象とし, さら に 1 次元ホログラム上の各要素ホログラムについては, こ れらの点光源のうち, この回折範囲内に存在する点光源の みについて計算すればよい。

また，（3)式より各要素ホログラムは独立に計算できる ので，筆者らはホログラムを並列計算機 CYBBERFLOW の各プロセッサに分割し, 並列に計算することによりリア ルタイム生成を行ってきた ${ }^{5) 6)}$ 。さらに, CYBERFLOW の特長であるべクトル演算機構を用いて（3)式における位 相差や余弦を計算することにより, 各プロセッサ内の 1 次 元ホログラムを一括して生成し, 高速化を図っている5)6).

\section{4. 並列化の最適化}

\section{1 従来の並列化手法における課題}

これまで筆者らは, ホログラムを単純に領域分割し, 各 プロセッサに分配していた ${ }^{5) 6}$. すなわち, 垂直方向の解 像度が 32 ラインのホログラムを 64 プロセッサで並列処理 する場合は, 図 3 のように各 1 次元ホログラムを中央で 2 分割し，それぞれを各プロセッサ(PE)に割り当てていた わけである. なお, 図 3 における括弧内の数字は, プロセ ッサ結合網の水平方向, 垂直方向の順に各プロセッサに割 り当てられた 1 次元の識別番号である.

一方, 前節で述べたように, サンプリング定理により音 響光学素子の最大空間周波数 $f_{s}$ によって決まる回折範囲 に含まれない情報は削除しなければならない．筆者らのシ ステムでは, $f_{s}$ は約 76.2 本 $/ \mathrm{mm}$ である.また, レンズ の倍率 $m$ は $1 / 2.94$, 入射光の波長 $\lambda$ は $632.8 \mathrm{~nm}$ である ので，(6)式より回折範囲 $\alpha$ は約 $0.1418 \mathrm{rad}$ となる.ま た, 1 次元ホログラム上で計算が必要な範囲 $i$ は, 点光源 とホログラムとの間の距離を $d$ とすると

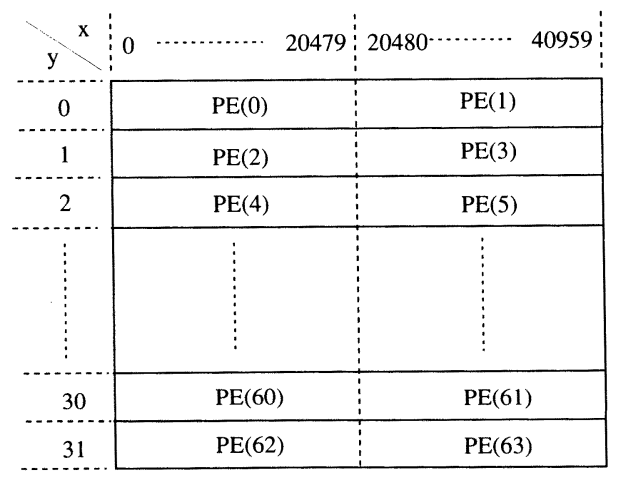

図 3 従来の並列化手法

Conventional method of distributing hologram among the processors. 


$$
l=2 d \tan (\alpha / 2)
$$

で求められる.例えば, 点光源がホログラムから $200 \mathrm{~mm}$ の距離にある場合, $l$ は $28.4 \mathrm{~mm}$ となる. 1 次元ホログ ラム長は約 $116 \mathrm{~mm}$ であるので, この場合は水平方向の 要素ホログラム 40960 点のうち約 $75.5 \%$ の情報が削除さ れることになる。

しかし, このような情報の削除を行うと, 点光源の $x$ 座標が 1 次元ホログラムの中央にある場合を除き, 2 つの プロセッサの負荷に差が生じることになる．さらに，隠面 消去10)を行うと, 各点光源に対する影響が 1 次元ホログ ラム全体に及ばなくなる。したがって，これによって $2 つ$ のプロセッサの負荷の差は更に大きくなる.

一方, 128 プロセッサで並列処理する場合は問題は更に 大きくなる．すなわち, 従来の並列化手法を拡張して図 4 のように各 1 次元ホログラムを 4 分割して, それぞれを異 なるプロセッサに割り当てると, ( 7 )式より点光源とホロ グラムとの間の距離が約 $408 \mathrm{~mm}$ 以下の場合は点光源の $x$ 座標にかかわらず，サンプリング定理による情報の削除に より, 各点光源の影響は 4 プロセッサのうちのたかだか 2 プロセッサにしか及ばないことになり，64プロセッサの 場合に対する $\mathrm{CGH}$ 生成速度の向上は期待できない. した がって, 計算機の並列度の向上により $\mathrm{CGH}$ 生成の高速化 を図るためには, 各 1 次元ホログラムの負荷を対応するプ ロセッサに均等に分散させることが不可欠である。

一方, 垂直方向の視差情報の削除により, 各 1 次元ホロ グラムの負荷はそれが属する $x-z$ 平面上の点光源数に比 例する. 一般に, 各 $x-z$ 平面上の点光源数は同一ではな いため, 各 1 次元ホログラムの負荷に差が生じる. このた め, 各 1 次元ホログラム上で均等に負荷を分散させても, プロセッサ間の負荷に差が生じることになる. 一方, 画像 全体で均一な正規化を行うためには, 全プロセッサに分散 した CGH データの最大值/最小值を求める必要があるた め，全プロセッサの計算が終了するまで正規化が行えな $い^{11)}$.このため, 各プロセッサの負荷に差があると処理効 率が大幅に低下する。したがって, 並列計算機の処理能力 を最大限に引き出すためには, 各 1 次元ホログラム上の負 荷だけではなく, 1 次元ホログラム間の負荷の差も考慮し

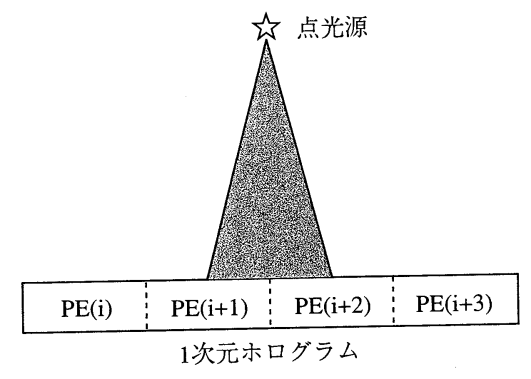

図 4 点光源の影響範囲 Affected area on a one-dimensional hologram by a point source.

論 文ロ並列計算機を用いた電子ホログラフィにおける負荷分散の最適化
て各プロセッサに均等に負荷を分散させることが必要であ る.

\section{2 並列化アルゴリズム}

( 3 ) 式より各要素ホログラムの計算は独立に行えるた め, 水平方向に隣接する要素ホログラムの計算を同一のプ ロセッサが行うことには, CGH の高速生成にとって全く 利点はない, 一方, 垂直方向に関しては, 通常の画像では 隣接する 1 次元ホログラム上の点光源数はほぼ等しいこと が多く, 離れるほど相関がなくなると考えられる。そこ で, 各プロセッサの負荷の差を縮小するために, 次のよう な並列化アルゴリズムを考案した。

（1）垂直解像度が $L$ の CGH を $N$ 台のプロセッサで 並列に生成する場合， $N$ 台のプロセッサを $h$ 台ず つ $v$ 個のブロックに分割する.ここで $h, v$ は $1 \leqq$ $h \leqq N, 1 \leqq v \leqq L ，$ かつ $h v=N$ を満たす任意の自 然数である.

（2）第 $j$ ブロックの第 $i$ プロセッサを $\mathrm{PE}[i, j]$ と表 すと, 垂直方向に $l$ 番目, 水平方向に $k$ 番目の要 素ホログラムは PE $[\bmod (k, h), \bmod (l, v)]$ に割 り当てる.

このアルゴリズムによる並列化の様子を図 5 に示す．図 中の小さな四角形が要素ホログラムであり, 各要素ホログ ラムが割り当てられるプロセッサ $\mathrm{PE}[i, j]$ を単に $i, j$ と 表している。このように並列化すると, 水平方向の要素ホ ログラム数がプロセッサ数に対して充分大きいため, 負荷 が水平方向に一様に分布していなくてもブロック内のプロ セッサに均等に負荷分散される。また, 各プロセッサ内の 同一 1 次元ホログラム上の要素ホログラムには, 従来と同 様ベクトル演算が活用できる.

一方，垂直方向に関しては，ブロック数 $v$ が 1 のとき に各プロセッサが計算する点光源数が等しくなるため負荷 が均等に分散され， $v$ が大きくなるほどブロック間の点光 源数の差が広がり, 負荷のばらつきが大きくなると考えら れる。しかし, $v$ が小さいほど, すなわちブロック内のプ ロセッサ数 $h$ が大きいほど, 各プロセッサに割り当てら

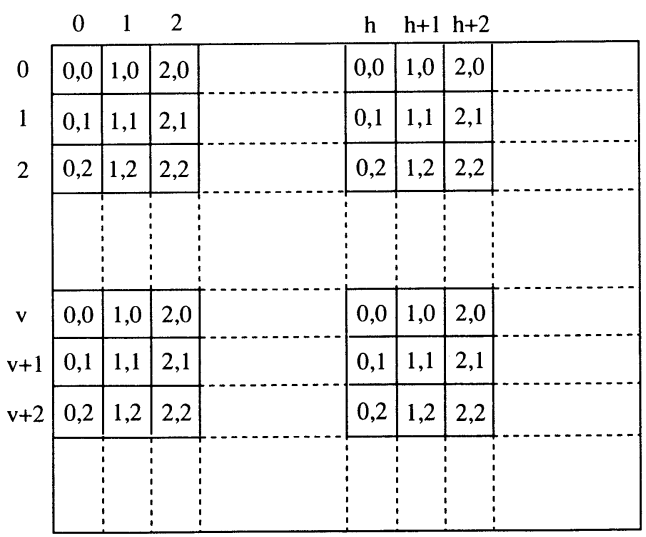

図 5 並列化手法

Method of distributing hologram among the processors.

(105) 223 
れる同一 1 次元ホログラム上の要素ホログラムが少なくな るため, ベクトル演算の要素数が少なくなり, その効果が 小さくなる，つまり，水平方向に関しては，各プロセッサ に割り当てられる同一 1 次元ホログラム上の要素ホログラ ム数がベクトル演算の最大要素数である 4096 以下で最大 になるときが最適であると考えられる．このように，hと vはトレードオフの関係にあり, 最適な組合せは画像によ って異なると考えられる。

\section{5. 実 験}

\section{1 実験結果}

本並列化アルゴリズムの効果を実証するとともに，パラ メータ $h, v$ の最適な值を求める方法を検討するために, 全点光源 1390 点のうち陰影処理後の振幅が正となる有効 な点光源 714 点が各 $x-z$ 平面に表 1 のように分布した物 体「円柱」で実験を行った，なお，以下ではこの有効な点 光源の数を単に点光源数と呼ぶことにする. また, 点光源 とホログラムの間の距離は約 $200 \mathrm{~mm}$ である.

実験結果を表 2 に示す。なお，表 2 における全実行時間 はフレームバッファへの転送を除く全体の実行時間であ り，この時間から初期化に要する時間を除いたものを求め る計算時間としている。 また, 計算速度比は従来の並列化 手法を用いて同数の 128 プロセッサで並列処理した場合の 計算速度との比を示している。

\section{2 実験結果の評価}

表 2 のように, $h=8, v=16$ の場合が最も高速であり, 従来の並列化手法 ${ }^{5}$ の 2.76 倍という結果が得られた。し たがって，この並列化手法は有効であるといえる。また， 4.1 節で述べたように, この場合は従来の並列化手法では 各点光源の影響がその 1 次元ホログラムを計算するプロセ ッサの半分にしか及ばないのに対して, 本手法ではこれら のすべてのプロセッサに及ぶので, 各点光源の計算を実行 するプロセッサ数が 2 倍になるため, このように 2 倍を越 える速度向上が得られたものと考えられる。

また，この実験では 128 プロセッサを用いて並列処理を 行い, 最も高速な $h=8, v=16$ の場合では初期化などの オーバヘッドを除くと, 有効な点光源 714 点の CGHを 1.36 秒で計算した.すなわち, 1 点光源あたりの CGH を 約 $1.9 \mathrm{~ms}$ で計算したわけである.

一方, 文献 9)では, CGH の計算方法を改善することに より, 汎用ワークステーションで 1 点光源あたり約 $10 \mathrm{~ms}$ で計算することができたとグラフに示されている ${ }^{9)}$ すな わち, 今回の実験結果の計算速度はこの約 5 倍である.

また，1次元ホログラムの計算に着目すると，筆者らは 本並列化手法と同様に 1 次元ホログラム上の各要素ホログ ラムの計算を各プロセッサに交互に割り当てることによ り，要素ホログラム数がこれを計算するプロセッサ数に比 べて充分大きい場合は, プロセッサ数に比例した処理速度 の向上が得られることを確認している12). したがって，パ
表 1 各 $x-z$ 平面上の有効点光源数

The number of effective point sources on each $x-z$ plane.

\begin{tabular}{c|c|c|c}
\hline \hline$y$ & 点光源 & $y$ & 点光源 \\
\hline 0 & 0 & 16 & 32 \\
\hline 1 & 13 & 17 & 31 \\
\hline 2 & 15 & 18 & 30 \\
\hline 3 & 19 & 19 & 30 \\
\hline 4 & 23 & 20 & 29 \\
\hline 5 & 25 & 21 & 27 \\
\hline 6 & 26 & 22 & 25 \\
\hline 7 & 28 & 23 & 21 \\
\hline 8 & 29 & 24 & 20 \\
\hline 9 & 31 & 25 & 17 \\
\hline 10 & 32 & 26 & 14 \\
\hline 11 & 31 & 27 & 12 \\
\hline 12 & 33 & 28 & 0 \\
\hline 13 & 33 & 29 & 0 \\
\hline 14 & 34 & 30 & 0 \\
\hline 15 & 32 & 31 & 0 \\
\hline
\end{tabular}

表 2 実験結果

The results of the experiment.

(単位：秒)

\begin{tabular}{r|c|c|c|c|c}
\hline \hline \multicolumn{1}{c|}{$h$} & $v$ & 全実行時間 & 初期化時間 & 計算時間 & 計算速度比 \\
\hline 4 & 32 & 2.36 & 0.65 & 1.71 & 2.19 \\
\hline 8 & 16 & 2.64 & 1.28 & 1.36 & 2.76 \\
\hline 16 & 8 & 2.69 & 1.28 & 1.41 & 2.66 \\
\hline 32 & 4 & 2.67 & 1.28 & 1.39 & 2.70 \\
\hline 64 & 2 & 2.91 & 1.24 & 1.67 & 2.25 \\
\hline 128 & 1 & 3.51 & 1.23 & 2.28 & 1.64 \\
\hline
\end{tabular}

ラメータ $v$ を一定にすれば，本並列化アルゴリズムにお いても計算速度はプロセッサ数に比例すると考えられる. 例えば, CYBERFLOW の論理的最大構成である 1024 プ ロセッサを用いれば, 計算速度がプロセッサ数に比例する とすると 1 点光源あたりの CGH を $238 \mu \mathrm{s}$ で計算できる と推定される。これは, 例えば Benton らが論理プロセッ サ数が 16384 である CM-2 を用いて達成した 1 点光源あ たりの CGH の計算時間 $299 \mu \mathrm{S}$ を上回る值である ${ }^{10)}$.

\section{3 実験結果の分析}

表 3 に, パラメータ $v$ の各值について各ブロックに含 まれる点光源数を示す. 表 3 ではブロック番号を $j$ として いる.なお, $v=32$ の場合は各ブロックに含まれる点光源 数は表 1 に示した各 $x-z$ 平面上の点光源数そのものであ り, $v=1$ の場合は全プロセッサが同じ数の点光源につい て計算することになる。 また, 各 1 次元ホログラムに含ま れる要素ホログラム数は 40960 である.つまり, 各プロセ ッサに割り当てられる同一 1 次元ホログラム上の要素ホロ 
表 3 各ブロックの有効点光源数

The number of effective point sources in each block.

\begin{tabular}{|c|c|c|c|c|}
\hline$j-v$ & 16 & 8 & 4 & 2 \\
\hline 0 & 32 & 82 & 179 & 358 \\
\hline 1 & 44 & 95 & 180 & 356 \\
\hline 2 & 45 & 94 & 179 & \\
\hline 3 & 49 & 94 & 176 & \\
\hline 4 & 52 & 97 & & \\
\hline 5 & 52 & 85 & & \\
\hline 6 & 51 & 85 & & \\
\hline 7 & 50 & 82 & & \\
\hline 8 & 50 & & & \\
\hline 9 & 51 & & & \\
\hline 10 & 49 & & & \\
\hline 11 & 45 & & & \\
\hline 12 & 45 & & & \\
\hline 13 & 33 & & & \\
\hline 14 & 34 & & & \\
\hline 15 & 32 & & & \\
\hline
\end{tabular}

グラム数, すなわちべクトル演算の要素数はこれを $h$ 等 分したものになる.

次に，これらのことを踏まえ，パラメータ $h, v$ の変更 に伴う実行速度の変化を分析する.まず， $h=128, v=1$ の場合は, 全プロセッサの点光源数が同じになるため負荷 は等しくなるが, ベクトル演算の要素数が最小になるた め, その効果が最も小さい. したがって, 実行速度が最も 遅くなるものと考えられる。

逆に, $h=4, v=32$ の場合は, ベクトル演算の要素数は 最大になるが, 最大要素数 4096 を越える.しかし, この 画像ではサンプリング定理による情報の削除により約 $75.5 \%$ 要素ホログラムの計算が削除されるので, この場 合もべクトル演算の要素数は最大要素数以下となる.した がって, ベクトル演算の効果はこの場合が最大となると考 えられるが, 実行速度は 2 番目に遅いという結果になっ た.これは各ブロックの点光源数は各 $x-z$ 平面上の点光 源数そのものであるため, ブロック間の点光源数の差が大 きく，異なるブロックのプロセッサ間にかなりの負荷の差 が生じたためであると考えられる。

これに対して, ベクトル演算の要素数が 2 番目に大きい $h=8, v=16$ の場合は, 表 3 からブロック間の点光源数の 差は $h=4, v=32$ の場合よりも小さいと考えられる.し たがって，異なるブロックのプロセッサ間の負荷の差は軽 減され，この場合の実行速度が最も速くなるものと考えら れる。

\section{6. 動的な並列化}

\section{1 負荷分散の評価}

前節では実験によって最適な並列化パラメー夕を求めた
表 4 負荷分散の評価

Evaluation of load distribution.

\begin{tabular}{r|r|r|l}
\hline \hline \multicolumn{1}{c|}{$h$} & $v$ & $P_{\max }$ & $C$ \\
\hline 4 & 32 & 34 & 1.524 \\
\hline 8 & 16 & 52 & 1.165 \\
\hline 16 & 8 & 97 & 1.087 \\
\hline 32 & 4 & 180 & 1.008 \\
\hline 64 & 2 & 358 & 1.003 \\
\hline 128 & 1 & 714 & 1 \\
\hline
\end{tabular}

が，動画のように多数の CGH をリアルタイムに生成する 場合などでは, 画像に応じて動的に並列化を行うことが要 求される。このためには, 負荷分散を定量的に評価する手 法を確立することが必要である。一方, 画像全体で均一な 正規化を行う場合は，実行時間は最も実行の終了が遅いプ ロセッサ，すなわち最も負荷が大きいプロセッサに左右さ れる11)。したがって, 負荷が最大のプロセッサを評価すれ ば，負荷分散を評価することができると考えられる。

そこで, 点光源数に着目し, 次式によって得られる值 $C$ によって負荷分散を評価することにする.

$$
C=\frac{N P_{\max }}{h P_{\text {all }}}
$$

ここで, $N$ は全プロセッサ数, $h$ は前節で述べた各ブロ ックのプロセッサ数, $P_{\max }$ は各ブロックの点光源数のう ちの最大のもの，P $P_{\text {all }}$ は全点光源数である.この式は負荷 が最大のプロセッサに, 全プロセッサに均等に負荷分散さ れた場合の何倍の負荷がかかっているかを示している。つ まり, 全プロセッサに均等に負荷分散された場合は $C=1$ となり，Cの值が大きいほど負荷にばらつきがあるとい うことができる。

前節の実験において $v$ の各值に対するCを表 4 に示 す.表 4 のように $v=32$ のときに $C$ は最大であり, $v=$ 16 にすると改善される。したがって, 前節の実験結果の 分析が裏付けられた。また, $v$ が小さいほど負荷のばらつ きが小さくなっていることがわかる。

\section{2 動的な並列化}

実験結果と上述の負荷分散の評価方法を踏まえ，次のよ うな前述の並列化アルゴリズムにおける最適なパラメータ を動的に決定する手法を提案する.

（1） ベクトル演算の要素数が最大となる $v$ を $v_{0}$, そ の次に大きい $v$ を $v_{1}$ とする.

（2）次の処理を $v$ が選択されるまで繰り返す.

$C_{0} / C_{1} \geqq K$ のきは $v_{1}$ を $v_{0}$, その次に大きい $v$ を $v_{1}$ と する。それ以外のときは $v_{0} を v$ として選択する。

ここで， $C_{0}, C_{1}$ はそれぞれ $v_{0}, v_{1}$ に対する $C$ の值, $K$ は適当な定数である。つまり，vをその次に大きいも のに変更するとべクトル演算の要素数は半分になるため処 理効率は低下するが，負荷分散の改善率 $C_{0} / C_{1}$ が $K$ 以上 
の場合は，これに変更することにする．例えば実験の場合 では, 表 4 から $K=1.2$ 程度に設定すれば最適なパラメー 夕 $v=16$ が選択されることになる.

このようにして, 最適な並列化パラメータを画像に応じ て動的に決定することができる．したがって，画像データ が動的に決定されるような場合においても, 最適な並列化 を行うことによってリアルタイム $\mathrm{CGH}$ 生成が可能になる ものと考えられる.

\section{7. むすび}

多数の点光源を含む電子ホログラムの高速生成を目指 し，最適な並列化を行うことができるアルゴリズムを提案 するとともに，128プロセッサを備えたデー夕駆動型並列 計算機 CYBERFLOW-128 を用いて実験を行った。その 結果, 従来の並列化手法に比べて 2.76 倍の処理速度の向 上を達成した。 また, このアルゴリズムでは, 更にプロセ ッサを増設した場合においても最適な並列化が行えると考 えられ，プロセッサ数に比例した CGH 生成速度の向上が 期待できる.

さらに，負荷分散を定量的に評価することにより，この アルゴリズムにおける最適な並列化パラメータを動的に決 定する手法を提案した。これにより，物体のデータが動的 に決定されるような場合においても最適な並列化が行え, $\mathrm{CGH}$ を高速に生成できると考えられる．また，更に計算 機の並列度を向上させれば, 多数の点光源を含む動画ホロ グラムのリアルタイム生成も可能になるものと期待でき る.

今後は, 提案した動的な並列化手法を用いて CGH を生 成し，その有効性を検証するとともに，CGH 生成の更な る高速化に取り組みたいと考える。

本研究を進める上で，多くの助言・協力をいただいた財 団法人イメージ情報科学研究所 上田主席研究員, 岡本主 席研究員, ならびに甲子園大学 梶木助教授に深く感謝い
たします。

\section{〔文献〕}

1）久保田敏弘：“ホログラフィ入門”, 朝倉書店 (1995)

2）辻内順平編著: “ホログラフィックディスプレイ”, 産業図書 (1990)

3）大越孝敬: “3 次元画像工学”, 朝倉書店 (1991)

4) P. St. Hilaire, S. A. Benton, M. Lucente, M. L. Jepsen, J. Kollin, H. Yoshikawa, J. Underkoffler: "Electronic Display System for Computational Holography”, SPIE Proc. No. 1212-20 (1990)

5）西田，中村，泰間，高橋，志水：“電子ホログラフィシステムにおける CGH 計算の高速化”, 第 24 回画像工学コンファレンス論文集, 8-2 (1993)

6）泰間, 高橋, 志水: “光学ホログラムとの合成により画質改善したリアル タイム電子ホログラフィ”, テレビ誌, 48, 10, pp. 1245-1252 (1994)

7）三浦, 川口, 田中, 大橋, 清水: “デー夕駆動計算機 EDDEN のアーキテク チャ”, 情処学論, 32, 7, pp. 831-848 (1991)

8）吉川, 亀山, 長尾: “動画像圧縮法のホログラフィック 3 次元画像への適 用”, 3 次元画像コンファレンス'95 講演論文集, 1-1（1995）

9）岩瀬, 吉川: “差分を用いたフレネルホログラム計算”, 1996 年信学会情 報・システムソサエティ大会講演論文集, D-306（1996）

10) S. A. Benton: "Experiments in Holographic Video Imaging", 3 D 映 像, 5, 2 (1991)

11）田中, 高橋, 志水: “リアルタイム電子ホログラフィの画質改善”, 3 次元 画像コンファレンス’96 講演論文集, 7-5 (1996)

12）田中, 高橋, 志水: “並列計算機を用いたリアルタイム電子ホログラフィ の高速化”, 映情学誌, 51, 5, pp. 737-739（1997）

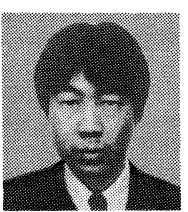

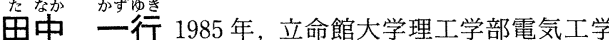
科卒業. 同年, 三洋電機(株)に入社. デー夕駆動型並列 計算機, 3 次元映像システム等の研究開発に従事. 1994 年より，(財)イメージ情報科学研究所に研究員として出 向中. 現在，電子ホログラフィに関する研究に従事．正 会員.

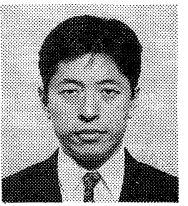

驾橋 秀也 1982 年, 大阪市立大学工学部電気工学 科卒業. 1984 年, 同大学大学院前期博士課程修了. 1987 年, 同大学大学院後期博士課程単位取得退学. 同 年, 大阪市立大学工学部助手, 1996 年, 同大学工学部 講師となり, 現在に至る. 光情報処理, 電子ホログラフ イに関する研究に従事. 博士(工学)。

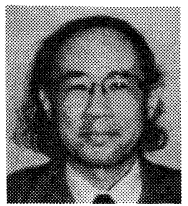

志水 英二 1963 年, 大阪大学工学部電子工学科卒 業. 同年，大阪市立大学工学部助手，1983 年，同大学 工学部電気工学科教授となり, 現在に至る. 電子回路, オプトエレクトロニクス, 光情報処理および電子ホログ ラフィの研究に従事。工学博士. 正会員。 